\title{
SISTEM PARKIR MENGGUNAKAN OCR (OPTICAL CHARACTER RECOGNITION) PLAT NOMER DAN IOT (INTERNET OF THINGS)
}

\author{
Muzan Ihda Khotmuniza ${ }^{1}$, Julian Sahertian ${ }^{2}$, Risa Helilintar ${ }^{3}$ \\ ${ }^{1,2,3)}$ Jurusan Teknik Informatika, Fakultas Teknik, Universitas Nusantara PGRI Kediri \\ Alamat: Jl.Kh. Achmad Dahlan Gang. 1 Kampus 2 UNP Kediri \\ E-mail:muzankhotmuniza@gmail.com ${ }^{1}$,juliansahertian@unpkediri.ac.id ${ }^{2}$,risa.helilintar@gmail.com ${ }^{3}$
}

\begin{abstract}
ABSTRAKS
Banyaknya kendaraan pribadi yang dimiliki penduduk perkotaan besar mengakibatkan berbagai permasalahan salah satunya adalah sulitnya menemukan lahan parkir yang kosong di tempat umum. Untuk mengatasi persmasalahan tersebut pada penelitian ini dibuat sebuah sistem parkir dengan pendekatan IoT (Internet of Things) serta memanfaatkan teknologi OCR (Optical Character Recognition) pengenalan plat nomor. Sistem ini memanfaatkan sensor ultrasonik sebagai pendeteksi kendaraan masuk, dan modul kamera untuk mengambil gambar plat nomor kendaraan yang terparkir. Sistem ini dirancang untuk mempermudah pendataan lahan kosong parkir dan pengguna dapat mengakses informasi lahan parkir dimanapun dan kapanpun. Pengujian sistem dilakukan dibagi menjadi dua bagian yaitu pengujian deteksi plat nomor kendaraan menggunakan kamera dan dan pengujian pengiriman data ke server. Hasil yang didapat dari pengujian yang dilakukan cukup memuaskan yaitu sistem mampu mengenali plat nomor kendaraan dengan akurasi 85, 21\%, dengan kecepatan pengiriman data maksimal saat semua slot parkir penuh adalah 17 detik.
\end{abstract}

Kata Kunci: Sistem Parkir, IoT, OCR, Sistem Informasi

\section{ABSTRACT}

The large number of private vehicles owned by large urban residents has resulted in various problems, one of which is the difficulty of finding empty parking lots in public places. To overcome these problems, in this study, a parking system with an IoT (Internet of Things) approach was created and utilized OCR (Optical Character Recognition) technology for number plate recognition. This system utilizes ultrasonic sensors to detect incoming vehicles, and a camera module to take pictures of parked vehicle license plates. This system is designed to simplify the data collection of empty parking lots and users can access parking lot information wherever and whenever. System testing is carried out divided into two parts, namely testing vehicle number plate detection using a camera and testing data delivery to the server. The results obtained from the tests carried out are quite satisfying, namely the system is able to recognize vehicle number plates with an accuracy of $85,21 \%$, with a maximum data transmission speed when all parking slots are full is 17 seconds.

Keywords: Parking Systems, IoT, OCR, Information Systems

\section{PENDAHULUAN}

\subsection{Latar Belakang}

Pada saat ini hampir semua orang memiliki kendaraan roda empat khususnya penduduk di kota besar, sayangnya pertumbuhan kendaraan ini tidak dibarengi dengan bertumbuhnya ruas jalan dan jumlah lahan parkir. Hal ini mengakibatkan masalah kemacetan dan juga sulitnya menemukan lahan parkir yang kosong

Berbagai upaya dilakukan untuk membuat lahan parkir se-efisien mungkin, dengan membangun sebuah gedung parkir ataupun membangun lahan parkir pada basemen sebuah gedung, namun hal ini tidak serta merta menyelesaikan masalah parkir kendaraan, masalah lain, sistem parkir yang ada dalam gedung belum memiliki sistem monitoring slot parkir yang dapat di akses pengguna sebelum parkir dan hanya memiliki informasi lahan telah penuh dan kosong pada saat lokasi parkir. Hal ini menyebabkan terbuangnya waktu dan lamanya seorang pengemudi kendaraan untuk menemukan slot parkir yang kosong. Diperlukan sebuah sistem parkir guna menyelesaikan masalah ini, Pada penelitian sebelumnya telah dibuat sistem parkir otomatis dengan memanfaatkan sensor Light Dependent Resistor (LDR), Resistor, Light Emitting Diode (LED) dengan mikrokontroler Raspberry pi 3 model B, lalu Raspberry pi 3 model B dan menggunakan MQTT mosquitto sebagai protokol untuk berkomunikasi dengan Virtual Private Server (VPS) dan terhubung ke aplikasi Telegram messenger dengan memberikan informasi mengenai lahan parkir kepada pengguna Android ataupun IOS[1].

Pada penelitian lain telah merancang sistem parkir dengan memanfaatkan sistem sms gateway guna mengetahui sebuah lahan parkir kosong atau telah terisi penuh, sistem ini memanfaatkan harware berupa modul GSM sim8001 dan microcontroller Arduino sebagai penerima SMS dari handphone atau smartphone[2].

Dari permasalahan diatas, penulis berupaya mengembangkan sebuah sistem IoT (Internet of Things) dengan dukungan perangkat sensor yang nantinya akan mendeteksi keberadaan sebuah kendaraan yang terparkir yang nantinya akan mengirimkan sebuah informasi berupa lokasi atau tempat parkir yang kosong ke sebuah web server dan 
sistem juga mampu mengenali plat nomor menggunakan teknologi OCR (Optical Character Recognition). Laman website ini yang nantinya dapat diakses oleh para pengendara yang akan memarkirkan kendaraanya guna mengetahui sebuah lahan parkir telah penuh terisi atau terdapat lahan parkir yang kosong. Dan bagi pengguna lahan yang telah parkir akan mendapatkan informasi berupa harga parkir yang dibayar dan lama waktu parkir kendaraan..

\subsection{Metode Penelitian}

Metode yang digunakan pada pengembangan sistem parkir ini adalah metode pengembangan sistem waterfall, dipilihnya metode ini adalah karena metode waterfall melakukan pendekatan sistematis dan berurutan dalam pembuatan sistem [3].

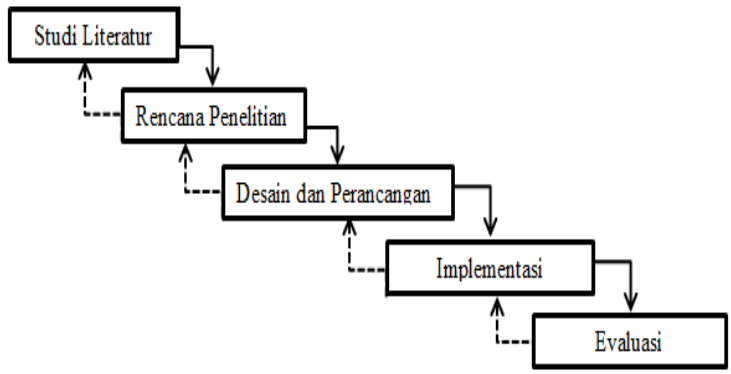

Gambar 1. Metode Pengembangan Sistem Waterfall

\section{PEMBAHASAN}

\subsection{Desain Sistem}

Pada gambar 1 merupakan perancangan dan alur sistem yang dibuat,yang terdiri dari 3 blok yaitu blok perangkat sensor, blok server halaman web dan server basis data, dan blok user. Dimana pada blok sensor terdapat sensor ultrasonik dan ESP32-Cam , dan pada blok server terdapat server basis data dan server halaman web. Halaman web akan di tampilkan pada blok user.

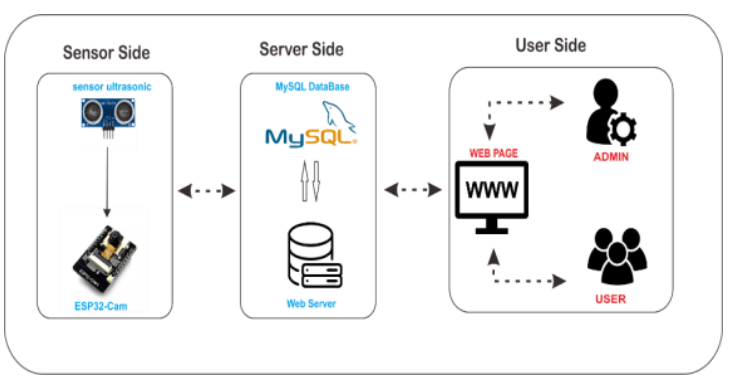

Gambar 2. Blok diagram Sistem Parkir

Perangkat sensor dipasang di tiap slot lahan parkir dan sensor ultrasonic akan terus menerus memancarkan gelombang ultrasonik, apabila sensor mendeteksi benda yang jaraknya kurang dari 1(Satu) Meter dari sensor maka status sensor akan berubah menjadi 1 atau terisi dan me-trigger kamera untuk melakukan pengambilan gambar. Dan apabila sensor tidak mendeteksi benda maka status sensor menjadi
0 atau lahan sedang kosong. Maka sensor akan metrigger ulang kamera agar mengambil gambar lahan yang sedang kosong yang selanjutnya diproses dikirim menuju server basis data. Data ini yang akan di tampilkan pada halaman web dan dapat di akses oleh pengguna maupun admin.

\subsection{Tesseract $\mathrm{OCR}$}

Tesseract OCR merupakan sebuah software pengenalan karakter OpenSource. Pertama kali dikenalkan oleh HP (Hewleet Packad) pada tahun 1984 sampai 1994 dan dimodifikasi untuk mendapatkan akurasi yang lebih tinggi pada tahun 1995. Pada tahun 2005 HP merilis Tesseract sebagai software OpenSourse dan portabel. Tetapi pada saat itu HP sudah tidak menggunakan Tesseract, dan sampai saat ini proses pengembangan Tesseract dipegang oleh Google [4].

Langkah pengenalan pada Tesseract dimuali dari menkonversi sebuah citra ke gambar biner, kemudian gambar biner memasuki langkah analisis komponen, dimana pada tahap ini akan mengektrasi garis tepi pada setiap karakter. Langkah ini sangat penting guna mengenali sebuah tulisan berwarna putih pada background berwarna hitam. Kemudian tahap selanjutnya pola garis teks dikonversi garis karaktek dan garis ini yang kemuidan akan dianalisa untuk mengetahui ukuran teks. Analisa ini dilakukan menggunakan definite spaces dan fuzzy space. Pada penelitian ini Tesseract dipergunakan sebagai pemroses gambar yang ditangkap oleh ESP32Camera dimana hasil pemrosesan ini akan berupa teks plat nomor yang nantinya akan di simpan dan di tampilakan pada halaman web.

\subsection{Hasil dan Analisis}

Pengujian dilakukan dengan membuat sebuah purwarupa alat, dimana terdapat 3 (tiga) sensor ultrasonik, 3 (tiga) ESP32-Camera , sebuah perangkat komputer sebagai server dan smartphone sebagai user atau client. Pengujian mencakup pengujian sensor tiap slot parkir, pengujian kecepatan transfer dan respon sensor ke server maupun sebaliknya, pengujian transfer dan respon dari server ke pengguna juga pengujian pengenalan plat nomot menggunakan Tesseract juga pengujian terhadap laman website.

\subsection{Pengujian Modul Kamera dan Wifi}

Pengujian modul kamera dilakukan dengan meletakkan kamera menghadap kearah objek yang akan di tangkap, dalam hal ini adalah sebuah plat nomor. Dan pengujian modul wifi dilakukan sama halnya dengan Ethernet Module yaitu dengan menghubungkan modul ke router yang nantinya akan terhubung ke server. Pengujian yang dilakukan pengujian penerimaan sinyal dan kecepatan transfer gambar dari modul ke server. Hasil pengujian dapat dilihat pada Tabel 1: 
Tabel 1. Hasil Pengujian

\begin{tabular}{|c|c|c|c|}
\hline $\begin{array}{c}\text { Jarak } \\
(\text { meter })\end{array}$ & $\begin{array}{c}\text { Sinyal } \\
(\mathrm{dbm})\end{array}$ & Waktu(ms) & Status \\
\hline 10 & -41 & $0-20$ & Terkirim \\
\hline 20 & -55 & $8-35$ & Terkirim \\
\hline 25 & -63 & $22-38$ & Terkirim \\
\hline 30 & -68 & $25-77$ & Terkirim \\
\hline
\end{tabular}

Gambar yang dikirim nantinya akan disimpan pada server database dan akan ditampilkan pada halaman web yang dapat diakses pengguna. Data gambar ini nantinya juga akan diproses menggunakan bantuan Tesseract OCR dan di simpan dalam bentuk text karakter plat nomor.

\subsection{Pengujian Tesseract $O C R$}

Tesseract OCR merupakan program yang digunakan untuk mengolah data gambar menjadi teks, dimana pada penelitian ini digunakan untuk mengidentifikasi gambar yang ditangkap ESP32Cam dan mengubahnya menjadi teks yang disimpan ke dalam basis data. Pengujian ini dilakukan dengan memproses citra plat nomor sejumlah 10 (sepuluh) buah. Plat nomor yang digunakan merupakan sampel yang didapat dari beberapa kendaraan roda empat. Pengujian bertujuan untuk menguji keakuratan dan tingkat error dari hasil pengolahan Tesseract. Hasil pengujian dapat dilihat pada tabel 2:

Tabel 2 Hasil Pengujian Pengenalan Plat Nomor

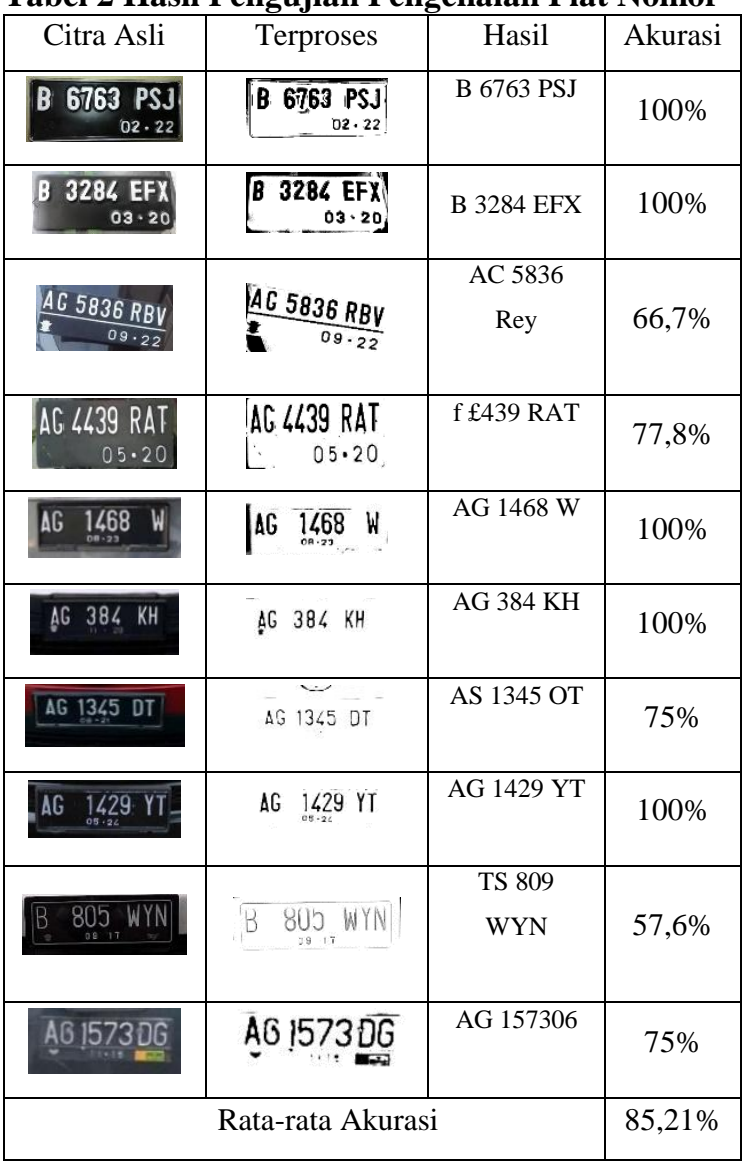

Dari tabel hasil pengujian, didapatkan hasil akurasi $85,21 \%$, hasil ini didapatkan dari pengujian ke 10 plat nomor, hasil pembacaan plat ini sangat bergantung dengan kualitas gambar yang ditangkap oleh ESP32-Cam, kondisi plat nomor dan pencahayaan.

\subsection{Kecepatan Pengiriman Data}

Pengujian kecepatan pengiriman data dari perangkat sensor dan kamera menuju webserver sangat diperlukan mengingat sistem dibuat adalah realtime, dimana diperlukan update data yang cepat. Kecepatan pengiriman data pada pengiriman dipengaru beberpa faktor, yaitu kecepatan pembacaan sensor, kecepatan pengambilan data dan delay program yang dibuat untuk mengirim data, dalam kasus ini delay yang diberikan pada tiap sensor adalah 5 detik. Pengujian ini dilakukan setelah semua alat telah dirangkai dan bekerja dengan baik. Hasil pengujian terdapat pada tabel 3 berikut:

Tabel 3 Hasil Pengujian Kecepatan Pengiriman

\begin{tabular}{|c|c|c|c|}
\hline $\begin{array}{c}\text { Status } \\
\text { sensor }\end{array}$ & $\begin{array}{c}\text { Waktu data } \\
\text { terkirim }\end{array}$ & $\begin{array}{c}\text { Pengiriman } \\
\text { nilai sensor }\end{array}$ & $\begin{array}{c}\text { Pengiriman } \\
\text { file gambar }\end{array}$ \\
\hline 1 terisi & 7 detik & Sukses & Sukses \\
\hline 2 terisi & 7 detik & Sukses & Sukses \\
\hline 3 terisi & 5 detik & Sukses & Sukses \\
\hline 1,2 terisi & 10 detik & Sukses & Sukses \\
\hline 1,3 terisi & 16 detik & Sukses & Sukses \\
\hline 2,3 terisi & 13 detik & Sukses & Sukses \\
\hline $1,2,3$ terisi & 17 detik & Sukses & Sukses \\
\hline
\end{tabular}

Berdasarkan dari hasil pengujian kecepatan pengiriman data yang dilakukan didapat hasil waktu data terkirim paling cepat adalah 5 detik pada saat slot parkir 3 terisi dan waktu data terkirim terlama adalah 17 detik saat semua slot parkir terisi. Secara kesulurahan data dapat terkirim ke server dengan sukses dari berbagai skenario pengujian.

\subsection{Pengujian Halaman Website}

Pengujian halaman website dilakukan setelah seluruh perangakat keras dan perangkat lunak telah terangkai dengan baik sesuai dengan desain perancangan yang ada. Pengujian dilakukan dengan melihat kecocokan data yang ditampilkan pada serial monitor, data yang dikirim menuju basis data dan data yang telah kita ukur sebelumnya. Pengujian perangkat keras hanya berupa perangkat purwarupa berukuran $30 \mathrm{~cm} \times 40 \mathrm{~cm}$.

Pengujian perangkat sensor dilakukan dengan meletakkan benda berupa purwarupa sebuah kendaraan roda empat, diharapkan sensor dapat mendeteksi sebuah benda yang nantinya dapat dilihat pada lampu indikator yang berubah warna dari merah menjadi hijau. Perubahan pada status 
sensor inilah yang nantinya akan dikirim ke server basis data. Pada server basis data, data akan disimpan dalam bentuk angka yang nantinya akan digunakan untuk mengubah status lahan yang ditampilkan pada halaman web. Data ini nantinya juga akan digunakan oleh kamera sebagai trigger untuk mengambil gambar pada bagian plat nomor kendaraan. Saat kamera mengambil gambar saat itu juga kamera akan mengirimkan gambar menuju web server yang nantinya data ini juga disimpan pada database. Perubahan data dapat dilihat dengan berubahnya data yang terdapat pada tabel database.

Pengujian terhadap halaman web dapat dilakukan dengan mengakses alamat server menggunakan sebuah telepon pintar. Dimana data yang telah disimpan pada basis data, selanjutnya ditambilkan dalam bentuk status lahan dan juga dalam bentuk gambar plat nomor yang teridentifikasi. Pada halaman pengguna pengguna dapat melihat setatus lahan parkir yang kosong maupun terisi dan informasi lengkap dari sebuah lahan parkir dapat dilihat dengan memilih salah satu lahan. Ada halaman detail ini lah pengguna lahan dapat melihat status lahan, gambar lahan yang digunakan maupun akan digunakan, data plat nomor kendaraan dan jumlah harga yang harus dibayarkan. Pengujian dikatakan berhasil ditandai dengan perubahan data sesuai dengan data yang dikirim dan disimpan pada database.

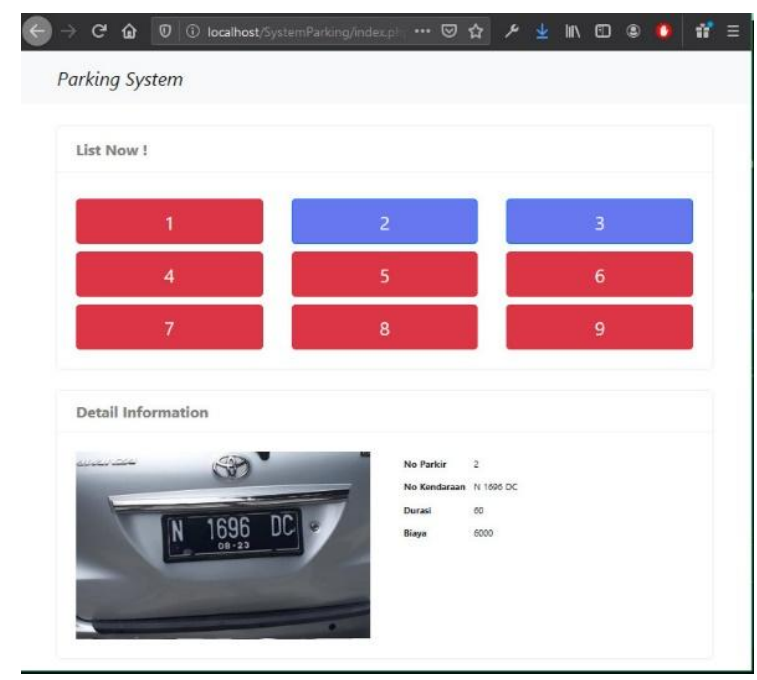

Gambar 3. Halaman Web Sistem Parkir

\section{KESIMPULAN}

Dari hasil pengujian sistem dan sensor yang telah dilakukan didapatkan hasil yang cukup memuaskan dari penggunaan sensor ultrasonic HCSR04 sebagai pendeteksi kendaraan pada lahan parkir dengan akurasi yang cukup baik. Pengiriman data sensor menuju server menggunakan ethernet module dapat dikatakan cukup baik, hanya saja terjadi delay yang cukup besar yang terlihat pada tabel 3 dimana apabila ketiga sensor mendeteksi objek secra bersamaan akan membutuhkan waktu 17 detik untuk mengupdate status lahan parkir.

Sama halnya dengan ethernet module, penggunaan modul kamera sebagai penangkap gambar dan mengirimkannya menuju server terjadi delay apabila ketiga sensor bekerja secara bersamaa, hal ini dikarenakan pembacaan yang dilakukan Arduino terjadi secara berurutan dari sensor $1 \mathrm{ke}$ sensor 3, begitu pula trigger yang menuju pada kamera. Hal ini akan berakibat pada informasi yang ditampilkan pada web dan biaya parkir yang harus dibayar. Pemrosesan plat nomor menggunakan bantuan Tesseract memiliki akurasi 85,21\%, hasil pengolahan gambar pada Tesseract sangat dipengaruhi oleh kualitas gambar yang ditangkap oleh modul kamera, juga pencahayaan pada lokasi parkir dan juga kondisi fisik pada plat nomor itu sendiri.

\section{PUSTAKA}

[1] Irwanda Kurniawan, Dr. Rendy Munadi, Nyoman Bogi Aditya Karna. 2019. Perancangan dan Implementasi Parkir Pintar Menggunakan Raspberry PI Melalui Telegram. Jurnal e-Proceeding of Engineering : Vol.6, No.2 Agustus 2019

[2] Sumarkantini, Lili Solihin, Woro Agus Nurtiyanto. 2020. Perancangan Parkir Pintar Bertingkat Menggunakan Metode SMS Gateway. Jurnal Saintika Unoam Vol. 2, No. 2, Januari 2020.

[3] Utami, Feri Hari. 2015. Rekayasa Perangkat Lunak. Yogyakarta. CV. BUDI UTAMA

[4] Go, E.B., Ha, Y.J., Choi, S.R., Lee, K.H. and Park, Y.H., 2011. An implementation of an android mobile system for extracting and retrieving texts from images. Journal of Digital Contents Society, 12(1), pp.57-67. 